\title{
SISTEM INFORMASI DATA USULAN PROYEK PADA BADAN PERENCANAAN PEMBANGUNAN DAERAH (BAPPEDA) CIANJUR
}

\author{
Ida Fitriani \\ Program Studi Teknik Informatika \\ Universitas Suryakancana \\ Idafitriani2011@gmail.com
}

\begin{abstract}
Abstrak
Sistem Informasi Manajemen merupakan penerapan sistem informasi di dalam suatu organisasi untuk mendukung informasiinformasi yang dibutuhkan oleh semua tingkatan manajemen.

Pengolahan informasi adalah himpunan aktifitas pokok computer menjadi bagian terpenting dari suatu instansi maupun suatu organisasi pengolahan informasi karena kecanggihan teknologi dan volume data yang diproses. Computer adalah sebuah alat pengolahan data elektronik yang dapat menolah data menjadi informasi dengan cepat, sebab itu suatu informasi yang berdasarkan computer akan jauh lebih baik dan cepat dibandingkan dengan sistem informasi yang diproses secara manual. Untuk membangun aplikasi yang dibuat menggunaka pemrograman Visual basic. Dalam suatu organisasi atau kantor pemerintah selalu memerlukan informasi, mengingat pentingnya kualitas sumber daya manusia yang ada memiliki tujuan akhir, guna memenuhi tujuan informasi kepada semua pihak khususnya bagi manajemen dan pengambil keputusan. Untuk itu didalam kemajuan organisasi atau lembaga kantor pemerintah akan diakatakan baik, bila tergantung pada arus informasi yang ada.
\end{abstract}

Kata Kunci: Sistem Informasi Manajemen, Basis Data, Komputer

\section{Pendahuluan}

Kemajuan suatu kantor pemerintah tidak terlepas dari perkembangan aktivitas yang terjadi didalamnya dan bagaimana pemecahan suatu masalah dengan baik, terutama penangan sistem informasi yang berbasis computer selain membantu para pengguna juga dapat mempermudah dalam pemecahan suatu masalah yang dihadapi BAPPEDA Cianjur yang pada saat ini sedang berupaya untuk melaksanakan tugas-tugas pembangunan diberbagai bidang baik dibidang Sumber Daya maupun dibidang Infrastruktur. Agar pembangunan dapat berjalan sesuai dengan rencanadan terukur dalam pembangunan, dalam hal ini peran aktif pemerintah daerah sangat menentukan tercapainya tujuan pembangunan. Sejauh ini untuk pemrosesan data usulan di Badan Perencanaan Pembangunan Daerah, masih membutuhkan waktu yang lama karena masih dikerjakan dengan cara manual karena keterbatasan sumber daya manusia untuk menangani pengolahaan data dengan media computer. Melalui program komputerisasi bila pengeloaannya tidak ditangani secara professional hasilnya tidak akan efisien dan efektif di dalam pelaksanaan Program.

\section{Metodologi}

Metodologi penilitan yang digunakan adalah deskriptif, yaitu suatu metode dengan cara mengumpulkan data, mengolah, serta menganalisa data yang telah terkumpul kemudian ditarik kesimpulan dan diberikan saran-saran yang diperlukan. Metode yang digunakan adalah : a. Pengumpulan data

1) Observasi

Yaitu pengamatan secara langsung terhadap objekobjek dikantor Badan Perencanaan Pembangunan Daerah (BAPPEDA) Kabupaten Tingkat II Cianjur, yang akan dimuat sebagai bahan penulisan.

2) Wawancara

Yaitu memperoleh keterangan secara langsung dengan pihak-pihak yang terkait dengan penyusunan laporan

3) Tinjuan Pustaka

Yaitu dengan membaca dari berbagai buku dan sumber lainnya agar mendapat data teoritis sebagai bahan penyusunan laporan.

\section{b. Tujuan Penulisan}

adapun tujuan penulisan tugas akhir ini adalah mengusulkan dan mengajukan sebuah program aplikasi pada sistem pemrosesan data usulan proyek pembangunan, agar sistem yang sudah berjalan dapat diketahui kelemahan dan masalah yang menyertai sistem serta mengajukan saran untuk diadakan untuk perubahan sistem agar tujuan yang diharapkan dapat tercapai secara optimal.

\section{Landasan Teori}

Teori-teori yang mendukung pembahasan 


\section{Aktifitas Kerja BAPPEDA secara umum}

Kantor Perencanaan Pembangunan Daerah (BAPPEDA) Kabupaten Cianjur, merupakan suatu kantor pemerintahan yang bergerak dibidang Perencanaan Pembangunan Daerah Cianjur diharapkan menjadi badan yang merancang perencanaan dan pembangunan di daerah Cianjur. yang mana sampai saat ini sudah memberikan pelayanaan yang baik, hasil yang baik dan citra yang baik dalam pembangunan perkotaan di Kabupaten Cianjur

\section{Sistem Informasi Manajemen}

\section{Konsep Sistem}

Mempelajari suatu sistem akan lebih oftimal hasilnya bila diketahui terlebih dahulu tentang suatu sistem. Lebih lanjut pengertian sistem didefinisikan menurut Jerry Fitze Gerald yang dikutip dari buku anilisis dan desain sistem informasi (Jogianto 1990: 1) adalah "Suatu jaringan kerja dari prosedur-prosedur yang saling berhubungan, berkumpul bersama-sama untuk melakukan suatu kegiatan atau untuk menyelesaiakan suatu sasaran".

Sebagai sesuatu yang dinamik, sebuah sistem memiliki pola tingkah laku yang berbeda suatu sistem lainnya, Tavrri D. Mahyuzir, (1989;4) menjelaskan bahwa sistem dibagi menjadi liam jenis yaitu sebagai berikut:

a) Deterministic System

Sistem dimana segala tingkah lakunya dapat diramalkan

b) Probabilistik System

Sistem dimana segala tingkah lakunya tidak dapat diramalkan

c) Closed System

Sistem yang tidak mempunyai relasi atau hubungan dengan lingkungan

d) Open System

Sistem yang mempunyai relasi atau hubungan dengan lingkungan

e) Stable System

Sistem yang hubungannya telah didefinisikan dengan jelas, apabila salah satu elemen ada kesalahan maka sistem akan berhenti.

Suatu sasaran sistem memiliki kecenderungan adanya berbagai unsur ketergantungan sebab satu sasaran tidak sepenuhnya memiliki unsure-unsur yang lengkap oleh karenanya akan terjadi suatu jaringan kerja yang satu sama lainnya saling mengisi (interkomplemen).

a. Karakteristik sistem

Suatu sistem mempunyai karakteristik atau sifatsifat tertentu, hal ini dikemukakan oleh jogianto (1990:3) dengan menjelaskan karakteristik sistem terdiri dari:

1) Komponen-komponen

2) Batas Sistem

3) Lingkunangan Luar sistem

4) Penghubung
5) Masukan

6) Keluaran

7) Pengolah

8) Sasaran

b. Klasifikasi Sistem

Suatu sistem dapat diklasifikasikan dari beberapa sudut pandang

1) Sistem Abstrak dan Sistem Fisik

Sistem abstrak adalah suatu susunan teratur gagasan atau konsepsi yang saling tergantun, sebagai contoh sistem teologi adalah sistem sebuah susunan mengenai tuhan, manusia dan sebagainya. Jadi sebuah sistem adalah bagian-bagian yang saling berkaitan dan saling berinteraksi untuk mencapai beberapa sasaran atau maksud. Sistem fisik lebih dari sekedar konseptual karena dapat memperlihatkan kegiatan atau prilaku

2) Sistem Alamiah dan Sistem Buatan

Sistem alamiah adalah sistem yang terjadi melalui prose salami, biukan buatan manusia, dan sistem fisik yang ada secara fisik

3) Sistem Tertentu dan Sistem Tak tentu

Sistem tertentu beroprasi dengan tingkah laku yang sudah diprediksi. Dan sistem tak tentu kondisi masa depannya tidak dapat diprediksi karena mengandung probabilitas.

4) Sistem Tertutup dan Sistem Terbuka

Yaitu sistem tertutup yang merupakan sistem yang tidak berhubungan dan tidak terpengaruh dengan lingkungan luarnya, sistem terbuka adalah sistem yang terhubung dan terpengaruh dengan lingkungan luarnya.

\section{Sistem Informasi}

Adalah data yang sudah diolah menjadi sebuah bentuk yang berarti bagi penerimanya dan bermanfaat dalam mengambil keputusan saat ini atau mendatang, dari sejumlah informasi belum tentu seluruhnya diserap oleh penerima informasi ada kemungkinan informasi tersebut didefinisikan terlebih dahulu yang mana dirasakan perlu atau tidak.

\section{Sistem Komputerisasi}

Supaya computer dapat digunakan untuk mengolah data, maka harus berbentuk sistem computer. Sistem adalah suatu jaringan dari pada elemen-elemen yang saling berhubungan, membentuk satu kesatuan untuk melaksanakan suatu tujuan pokok dari sistem tersebut.

\section{Konsep Manajemen}

Manajemen adalah suatu proses terpadu yang dibuat, dipelihara serta dijalankan oleh individu-individu yang diberi wewenang untuk mencapai sasaran atau tujuan organisasi.

Untuk itu manajemen memiliki empat bagian kegiatan yaitu:

a) Planning (perencanaan) 
b) Directing (Pengerahan)

c) Organizing (Pengorganisasian)

d) Controlling ( Pengendalian)

Keempat kegiatan manajemen tersebut dilaksanakan secara terus menerus, sehingga membentuk suatu daur yang hanya bisa selesai bila tujuan telah selasai.

Jadi Sistem Informasi Manajemen (SIM) adalah seperangkat alat yang digunakan untuk membuat suatu pendukung keputusan dalam menjalankan kegiatan manajemen dengan cara memberikan informasi berdasarkan pandangan secara sistem, sehingga dapat mengambil keputusan dengan tepat.

\section{Sistem Informasi Manajemen}

Sistem informasi menurut Robert A. Leitch yang dikutip dari buku analisis dan desain Sistem Informasi (Jogianto, 1990, 11) adalah :" sistem didalam suatu organisasi yang mempertemukan kebutuhan pengolahan transaksi harian, mendukung operasi yang bersifat manajerial dan kegiatan strategis dari suatu organisasi dan menyediakan pihak luar tertentu dengan laporanlaporan yang ditentukan

\section{Komponen Sistem Informasi}

a) Blok Masukan

Yaitu inputan yang mewakili data masuk kedalam sistem informasi.

b) Blok Model

Yaitu blok yang terdiri dari kombinasi prosedur. Logika dan model matematika yang akan memanipulasi data input dan data yang tersimpan dibasis data dengan cara yang sudah tertentu untuk menghasilkan kaluaran yang diinginkan

c) Blok Keluaran

Teknologi yang digunakan untuk menerima input, menjelaskan model, menyimpan dan mengakses data, menghasilkan dan mengirimkan keluaran dan membantu pengendalian dari sistem secara keseluruhan.

d) Blok basis data

Basia data (Database) merupakan kumpulan dari data yang saling berhubungan satu dengan lainnya, tersimpan diperangkat keras computer dan digunakan perangkat lunak untuk memanipulasinya.

e) Blok Kendali

Beberapa pengendalain perlu dirancang dan diterapkan untuk meyakinkan bahwa hal-hal yang dapat merusak sistem dapat dicegah ataupun bial terlanjur terjadi kesalahan-kesalahan dapat langsung diatasi.

\section{Database}

Data base merupakan salah satu komponen yang penting dalam sistem informasi, karena merupakan dasar dalam menyediakan informasi bagi para pemakai. Database merupakan kumpulan dari data yang saling berhubungan anata satu dengan yang lainnya yang tersimpan pada perangkat keras computer dan digunakan perangkat lunak untuk memanipulasinya, guna memenuhi kebutuhan pembentukan informasi.

Penerapan Database dalam Sistem Informasi disebut dengan data base sistem. Sistem data base merupakan sistem informasi yang mengintegrasikan kumpulan dari data-data yang saling berhubungan satu dengan yang lainnya dan membuat tersedia untuk beberapa aplikasi yang bermacam-macam. Sistem pengolahan basis data (DBMS) merupakan perangkat lunak dari sistem database yang digunakan untuk memanipulasi database. Adapun memanipulasi data terbagi menjadi:

a. Proses Pemeliharan Data

i. Proses Pemasukan (Entry)

ii. Proses Penambahan (Add)

iii. Proses Pengubahan (Update)

iv. Proses Penghapusan (Delete)

v. Proses pembuatan File (back-up)

vi. Proses Perbaikan Kerusakan (Recovery data)

b. Proses Pencarian Data Kembali
i. $\quad$ Proses Searching
ii. Penggunaan Key-Search berupa kode.

Teknik Normalisasi adalah proses pengelompokan data elemen menjadi tabel-tabel yang menunjukan entity dan relasinya. Bentuk-bentuk teknik tersebut terdiri dari:

a. Bentuk tidak Normal Unnormalized Form)

b. Bentuk normal kesatu (INF/ First Normal Form)

c. Bentuk Normal kedua (2NF/Second Normal Form)

d. Bentuk Normal Ketiga (3NF/ Third Normal Form)

e. Bentuk Normal keempat (4NF)

f. Bentuk Normal kelima (5NF)

g. Boyce-codd Normal Form (BCNF)

Teknik entity relationalship adalah relasi antara dua file atau dua tabel yang dapat dikategorikan menjadi tiga macam. Dalam teknik ini menggunakan tiga buah bentuk relasi yaitu:
a. One to one Relationship
b. One to many Relationaship
c. Many to many Relationship

Database digunakan untuk mengatasi masalahmasalah pada penyusunan data seperti:

a. Redudansi \&bIkonsisten Data

b. Kesuliatan Pengaksesan Data

c. Isolasi Data untuk Standarisasi

d. Multiple User

e. Masalah keamanan

f. Masalah Integritas (kesatuan) database

g. Masalah data Independence (Kebebasan Data) 
Tahapan Pengembangan Sistem tahapan utama dan langkah-langkah dalam proses pengembangan sistem George M.Scott yang dikutip dari buku analisis dan desain sistem informasi (Jogianto 1990:50) diantaranya:

1. Studi Pendahuluan (Preliminary Study)
a. Penemuan Masalah
b. Studi Pendahuluan
c. Laporan Singkat Study pendahuluan

2. Analisis Sistem (System Analysis)
a. Perencanaan Masalah
b. Penelitian Sistem yang ada
c. Definisi masalah
d. Analisis sistem
e. Kebutuhan-kebutuhan sistem
f. Laporan Rancang bangung

3. Desain System (System Desaign)
a. Desain secara makro
b. Desain Terinci
c. Rancang bangun Desain

4. Implementasi Sistem (System Implementasi)
a. Pelatihan
b. Penyeleksian Program \& Pelatihan
c. Pemrograman
d. Persiapan Tempat
e. Instalasi
f. Konversi
g. Penerimaan

Menurut A. Ziya Aktas yang dikutip dari buku analisis dan desain sistem informasi (Jogianto 1990;5) tahaptahap didalam pengembangan sistem adalah sebagai berikut:

1. Perencanaan (Planning)
a. Permintaan Untuk Suatu Studi suatu sistem
b. Investigasi Awal
c. Studi kelayakan

2. Analisis (Analysis)
a. Definisi kembali masalah
b. Pahami Sistem ada
c. Tentukan kebutuhan-kebutuhan pemakai dan hambatan-hambatan pada suatu sistem baru
d. Model logika dari pemecahan yang direkomendasikan.

3. Desain Secara Fisik (Fhysikal Design)
a. Desain Sistem atau desain secara umum
b. Desain terinci dan desain khusus

4. Implementasi atau kontruksi (implementation or Contruction)
a. Pembangunan Sistem
b. Pengetesan
c. Instalasi/konversi
d. Operation

e. Kaji Ulang Setelah Implementsi

\section{Perawatan (Maintanance)}

\section{Visual Basic 5.0}

Microsoft Visual Basic adalah sebuah bahasa pemrograman yang bekerja dalam lingkup Microsoft Windows. Microsoft Visual Basic 5.0 merupakan suatu program aplikasi ini dapat membantu memecahkan permasalahan yang interaktif dengan tampilan yang begitu menawan.

\section{Analisa dan Desain}

1) Analisa Sistem Seperti telah dijelaskan fungsi dari BAPPEDA dalam pembangunan, yang dimana penggunanya ditunjukan bagi pihak pengambil keputusan, maupun pihak lain yang memerlukannya.

Untuk dapat meningkatkan pelayanan dan kemudahan dalam mencari data usulan keperoyekan. Maka beberapa permasalahan yang terdapat pada bagian perencanaan perlu segera diatasi, yaitu dengan jalan memperbaiki sistem yang lebih mengarah kepada sistem data usulan keproyekan yang dibantu dengan menggunakan computer dalam menangani proses pemasukan data usulan keproyekan, khususnya masalah data usulan proyek pembangunan. Untuk itu perlu dianalisis mengenai beberapa hal yang terjadi sebelum mendesain sistem baru untuk mengatasi antara lain:
a. Sulitnya melihat data Usulan proyek
b. Informasi Kurang Akurat

2) Desain Sistem

Setelah tahapan analisis selsesai dilakukan, selanjutnya adalah melakukan desain sistem. Dan tahapan ini langkah pendesainan dibagi kedalam dua bagian

\section{a. Desain Sistem}

Sebelum dilakukan desain sistem terinci, perlu terlebih dahulu dilakukan sistem secara umum. Upaya ini bertujuan memberikan gambar secara umum kepada pemakai tentang sistem baru.

1. Pertimbangan-pertimbangan Desain

a. Efektifitas pengolahan data akan dicapai dengan cara menempatkan alat bantu computer sebagai unit pengolahan data. Dimana semua data yang menyangkut informasi tentang pembangunan di cianjur dapat disusun sedemikian rupa, sehingga akan memudahkan para pemakai dan pengguna informasi.

b. Pengolahan data dengan bantuan computer ini dibuat dengan tujuan untuk menyediakan jalur antara pemakai dengan sistem yang cepat, tepat dan mudah diktrol oleh bahasa pemrograman visual basic untuk memanipulasi data base 
yanga ada, desain input dan output dibuat dengan tujuan untuk memudahkan komunikasi bagi pemakai, menerapkan fungsi validasi pada programnya, penggunaan kode pada data-data yang bersifat unik dan pesan-pesan yang akan tampilkan kepada pemakai pada saat kondisi tertentu, serta menyediakan utility program untuk keperluan pemakai. Disamping itu pula pada sistem baru ini juga menyediakan kemudahan dalam mengembangkan proses data yang lama ke proses data yang baru, yaitu dengan kriteria dan batasan yang telah ada.

2. Desain Model Secara Umum

Dalam desain model secara umum ini, maka ada beberapa hal yang akan dibahas, khususnya menyangkut sistem yang akan dibuat. Untuk lebih jelasnya, maka akan dijelaskan mengenai sistem data informasi usulan proyek pembangunan yang ada dan yang berlaku pada saat ini. Dan kemudian akan dibahas mengenai data flow diagram atau diagram tersebut akan diperoleh beberapa file sebagai bahan untuk melakukan pendesainan database lebih lanjut.

3. Analisis Masalah

Mengamati permasalahan dari sistem data informasi proyek pembangunan yang sedang berjalan di Badan Perencanaan Pembangunan Daerah Kabupaten Cianjur, maka dapat dianalisis permalasahan yang terjadi adalah sebagai berikut:

a. Pencatatan dan masih dilakukan dengan cara manual

b. Dalam pencarian data tentang data usulan proyek pembangunan banyak mengalami kesulitan disebabkan banyaknya data yang tidak terarsip dengan terurut, sehingga informasi yang sangat dibutuhkan pada saat sangat dibutuhkan menjadi lambat dan tidak efisien.

c. Dalam pembuatan laporan tidak dapat dilakukan dengan cepat karena terlebih dahulu harus membuka arsip-arsip atau dokumendokumen sehingga membutuhkan waktu yang lama.

Hasil dari analisa permasalahan tersebut, maka dapat dianalisis sebagai berikut:

1. Proses pengolahan data atau informasi yang sedang berjalan kurang cepat dan efisien disebabkan karena banyaknya data-data yang ditulis ataupun secara manual banyak mengalami kesulitan.

2. Perlu adanya usaha penerapan alternative yang lebih menyempurnakan proses sistem informasi di BAPEDA Cianjur, sehingga azas efiseinsi dan efektivitas dapat tercapai sesuai dengan apa yang diinginkan.
Dalam merancang Sistem diperlukan satu langkah pemecahan masalah untuk dapat menyelasaikan dan mempermudah dalam hal penyelesaian masalah-masalah yang dihadapi. Untuk itu diperlukan langkah-langkah pemecahan sebagai berikut:

a. Pengumpulan Data

Pada tahap ini dilakukan pengumpulan data-data dan dokumen-dokumen yang dibutuhkan, dalam pengumpulan data ini dilakukan melalui metode observasi langsung ketujuan untuk menentukan data yang ada, serta melakukan wawancara dengan pihakpihak yang bersangkutan sesuai dengan sistem yang dirancang, dan untuk melengkapi data memanfaatkan pustaka sebagai pelengkap.

b. Analisis Data

Tahap analisis data adalah tahap yang dilakukan untuk mensepsifikasi data-data yang diperlukan dalam perancangan sistem. Dalam analisi ini diperlukan untuk mengambil data-data yang akan diolah untuk menghasilkan informasi baru.dan akan dimasukan kedalam media-media yang pada akhirnya akan disimpan dalam media penyimpanan dan diakses oleh computer dengan konsep database

c. Perancangan

Langkah selanjutnya yaitu tahap rancangan terhadap sistem yang akan dibuat mengenai desain sistem yang akan diusulkan meliputi perancangan sistem baru yaitu rancangan desain database

d. Implementasi

Langkah kerja berikutnya adalah merupakan segala sesuatu yang telah dirancang secara rinci. Sasarannya adalah menyimpulkan semua kegiatan menerapkan sistem sesuai dengan spesifikasi yang telah ditentukan.

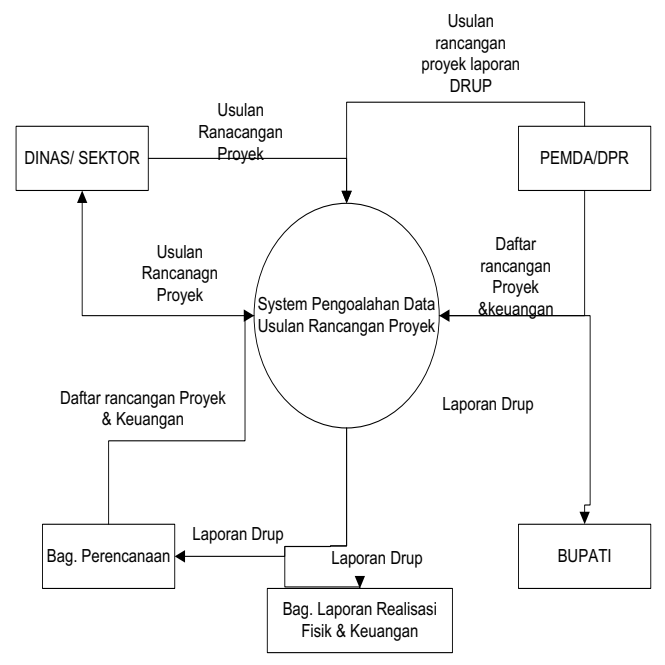

Level 0 


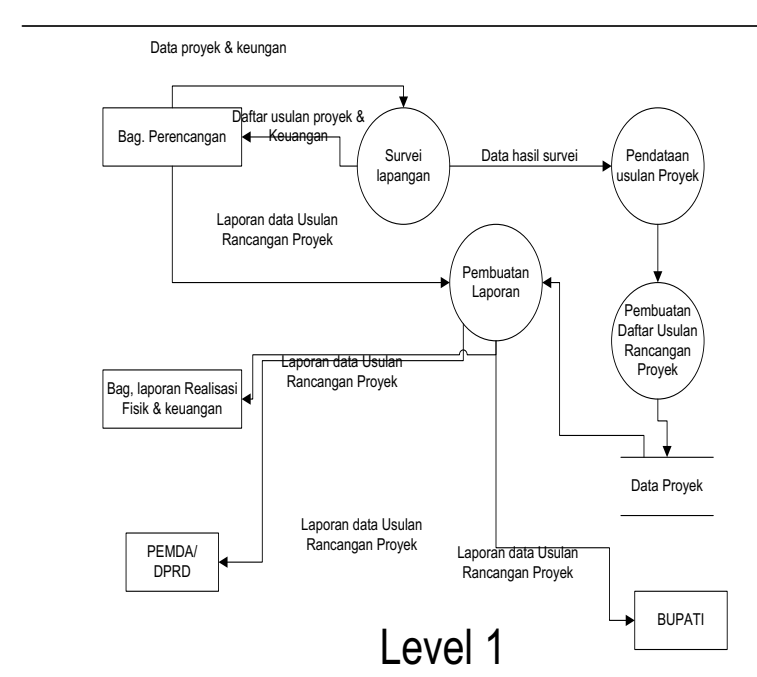

\section{a. Deskripsi Aliran Data}

Pada Tahap analisis, penggunaan deskripsi aliran data ini sangat membantu sekali dalam melihat sistem secara logika, berikut ini akan digambarkan data yang lama dan aliran data yang akan dirancang.

\section{b. Deskripsi Aliran Data Contex Diagram}

Proses contex diagram ini adalah untuk mewakili proses dari sistem dan menggambarkan hubungan input/output antara sistem dengan dunia luarnya (kesatuan Luar). Berikut ini dapat digambarkan contex diagram pada sistem lama dan sistem baru.

Pendataan usulan proyek dialoh atau diproses dengan menggunakan sistem komputerisasi, maka akan lebih mempercepat dan mempermudah dalam prosses pendataan usulan proyek dibagian perencanaan.

c. Data Flow Diagram

data flow diagram yang akan dibahas disini adalah menjelaskan arus informasi mengenai sistem informasi data usulan proyek yang saat ini sedang berjalan, dimana data flow diagram tersebut akan diperoleh beberapa file data yang dijadikan kriteria dalam mendesain database.

\section{c. Data Flow Diagram}

Data Flow Diagram yang akan dibahas adalah menjelaskan arus Informasi mengenai sistem data usulan proyek yang saat ini sedang berjalan dimana data flow diagram tersebut diperoleh beberapa file data yang dijadikan kriteria dalam mendesain database

\section{Pertimbangan-pertimbangan Desain}

1) Efektivitas pengolahan data akan tercapai dengan cara menempatkan alat bantu computer sebagai unit pengolahan data. Dimana semua data yang menyangkut informasi tentang pembangunan di cianjur dapat disusun sedemikan rupa, sehingga akan memudahkan para pemakai dan pengguna informasi.

2) Pengolahan data dengan bantuan computer ini dibuat dengan tujuan untuk menyediakan jalur antara pemakai dengan sistem yang cepat, tepat dan mudah dikontrol oleh bahasa pemrograman visual basic untuk manipulasi data base yang ada, desain input dan output dibuat dengan tujuan untuk memudahkan komunikasi bagi pemakai, menerapkan fungsi validasi pada programnya, penggunaan kode pada data-data yang bersifat unik dan pesan-pesan yang akan ditampilakan kepada pemakai pada saat kondisi tertentu, serta menyediakan utility program untuk keperluan pemakai. Disamping itu pula pada sistem baru ini juga menyediakan kemudahan dalam mengembangkan proses data yang lama ke proses data yang baru, yaitu dengan kriteria dan batasan yang telah ada.

\section{b. Desain Sistem terinci.}

Desain sistem secara terinci ini merupakan kelanjutan sisten umum.

\section{Desain Input}

Masukan (input) merupakan awal dimulainya proses informasi, yang sehubungan dengan alat bantu yang digunkana yaitu computer. Dimana proses pemasukan data ke computer harus efisien dan efektif dalam cara pemakaiannya. Informasi data usulan proyek merupakan pemasukan untuk sistem informasi tidak lepas dari data yang di masukan.

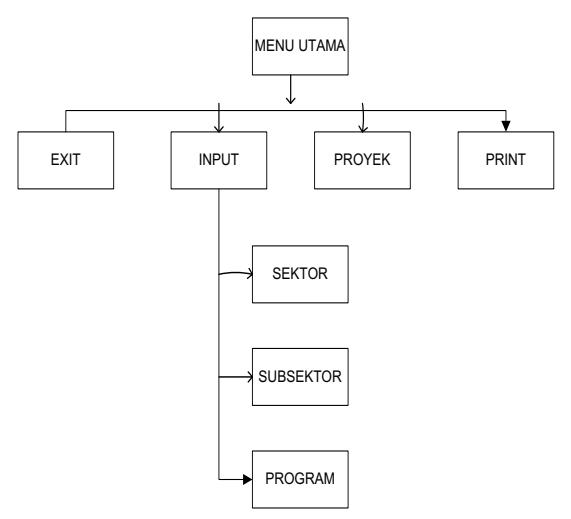

\section{Desain Output}

Didalam mendesain bentuk disain output terinci ini yang mana output (keluaran) adalah produk dari sistem informasi yang dapat dilihat. Output dapat berupa hasil media kertas, mikrifilm ataupun hasil media lunak berupa tampilan dilayar monitor, adapun untuk output dimedia kertas mengenai bentuk hasil pengeluarannya dari desain dialog layar tampilan.

\section{Implementasi Sistem}

Tahapan implementasi sistem merupakan tahap meletakan sistem supaya siap dioprasikan. Kegiatan implememtasi dilakukan dengan dasar kegiatan yang telah direncanakan dalam implementasi. Tahap ini termasuk juga kegiatan penulisan program, yaitu dengan maksud memperoleh hasil yang sesuai seperti pada desain dan sistem terinci. Hasil program yang sesuai dengan desainnya akan menghasilkan program yang sesuai dengan yang dibutuhkan oleh pemakai. 
a. Kegiatan Implementasi

Kegiatan implementasi dilakukan dengan dasar kegiatan yang telah direncanakan. Kegiatankegiatan yang dapat dilakukan dalam tahap implementasi ini adalah sebagai berikut:

1) Proses Pengujian Program

Setelah program diterapkan, maka program harus bebas terlebih dahulu dari kesalahan-kesalahan. Oleh sebab itu program harus di test untuk menemukan kesalahan-kesalahan yang mungkin dapat terjadi. Maksud program ditest yaitu untuk tiap-tiap modul, dan dilanjutkan dengan pengetesan untuk semua modul yang telah dirangakai.

2) Proteksi dan Backup Terhadap Data

Untuk menjaga segala kemungkinan yang terjadi pada program atau data, maka diperlukan sekali keamanan data yaitu dengan melakukan proteksi dan backup terhadap data. Proteksi terhadap data dapat dilakukan dengan memberikan suatu hak akses terhadap suatu file berdasarkan pengguna yang akan mengakses terhadap pemilik file dan informasi tentang pengaksesan dapat disimpan dalam suatu Accses Contor list (ACL) juga dapat dilakukan pada sistem dengan membuat password agar data yang ada dikomputer terjaga.

a. Keunggulan Sistem

1) Kecepatan dan kecermatan dan pengolahan data pada bidang perencanaan efisen dan efektif

2) Pelacakan terhadap kesalahan dapat dengan cepat diketahui

3) Pengarsipan dan penyimpanan data menjadi lebih akurat dan tersusun

b. Meningkatkan Sumber Daya Manusia

Manusia merupakan salah satu dari sekian banyak faktor yang menentukan keberhasilan dari suatu sistem. Organisasi harus memilih dan melatih personil untuk menambah pengetahuan dan kecakapan guna melaksanakan jabatan tertentu.

c. Perangkat Bantu

Perangkat bantu yang digunakan adalah program komputerisasi di Badan Perencanaan Pembangunan Daerah adalah:

1) Perangkat Keras

2) Perangkat Lunak

\section{Simpulan dan Saran}

\section{Simpulan}

Badan perencanaan pembangunan Daerah merupakan lembaga pemerintahan yang dibentuk berdasarkan kebutuhan, perkembangan dan kemajuan dibidang pemerintahan, lembaga ini diharapkan sebagai perencana membantu dalam bidang perencanaan daerah. Dalam sistem informasi data usulan proyek masih dilakukan secara manual, sehingga dalam sistem informasi data usulan proyek mengalami keterlambatan pada saat yang dibutuhkan. Dengan lambatnya informasi tersebut menunjukan bahwa dalam pengolahan data secara manual kurang efektif dan efisien, sehingga dapat mengakibatkan pemborosan waktu dan besarnya biaya yang dikeluarkan serta menghambat dalam proses pengambilan keputusan. Tugas yang paling dominan dalam aktivitasnya adalah pada bidang perencanaan pembangunan, maka diperlukan satu cara untuk membuat laporan secara cepat dan teliti.

\section{Saran-saran}

Agar sistem kerja pada bidang perencanaan pada lembaga ini dapat berjalan secara optimal, maka penyusun menyarankan hal-hal berikut:

a. Diadakan perubahan sistem kerja dengan memanfaatkan sarana yang tersedia

b. Penambahan sarana yang belum tersedia diantaranya dalam menunjang proses perencanaan data usulan proyek sehingga mempercepat dan mempermudah kerja pada sector perencanaan data usulan proyek.

c. Pembenahan arsip-arsip dan dokumen yang tercecer sehingga dapat ditempatkan pada tempat baik

d. Penambahan sumber daya manusia yang didukunh oleh tenaga yang terampil dan berdedikasi tinggi 


\section{DAFTAR PUSTAKA}

Aktifa, N. (2013). Dasar-dasar Akuntansi Perkantoran. Jakarta: Laksana.

Al -Bahra Bin Ladjamudin. (2008). Analisa dan Desain Sistem Informasi. Yogyakarta: Graha Ilmu.

Davis B. Gordon (1993) kerangka dasar sistem Informasi Manajemen, Jakarta, Midas Surya Grafindo.

Fathansyah. (2002). Basis Data. Bandung: Informatika.

Hartono, J. (2004). Pengenalan Komputer. Yogyakarta: Andi.

Jogiyanto. (2005). Analisis dan Desain Sistem Informasi. Yogyakarta: Andi.

Ladjamudin, A. B. (2008). Analisis dan Desai Sistem Informasi. Klaten: Gava Media.

Pressman, R. S. (2010). Pendekatan Praktisi Perangkat Lunak Edisi 7. Yogyakarta: Andi.

Turban, M. W. (1999). Pengenalan Sistem Informasi. Yogyakarta: Andi. 